\title{
PILOT PROJECT SAND GROYNES DELFLAND COAST
}

\author{
R. Hoekstra ${ }^{1}$, D.J.R. Walstra ${ }^{1,2}$, C.S Swinkels ${ }^{1}$
}

\begin{abstract}
In October and November 2009 a pilot project has been executed at the Delfland Coast in the Netherlands, constructing three small sandy headlands called Sand Groynes. Sand Groynes are nourished from the shore in seaward direction and anticipated to redistribute in the alongshore due to the impact of waves and currents to create the sediment buffer in the upper shoreface. The results presented in this paper intend to contribute to the assessment of Sand Groynes as a commonly applied nourishment method to maintain sandy coastlines. The morphological evolution of the Sand Groynes has been monitored by regularly conducting bathymetry surveys, resulting in a series of available bathymetry surveys. It is observed that the Sand Groynes have been redistributed in the alongshore, mainly in northward direction driven by dominant southwesterly wave conditions. Furthermore, data analysis suggests that Sand Groynes have a trapping capacity for alongshore supplied sand originating from upstream located Sand Groynes. A Delft3D numerical model has been set up to verify whether the morphological evolution of Sand Groynes can be properly hindcasted. Although the model has been set up in 2DH mode, hindcast results show good agreement with the morphological evolution of Sand Groynes based on field data. Trends of alongshore redistribution of Sand Groynes are well reproduced. Still the model performance could be improved, for instance by implementation of $3 \mathrm{D}$ velocity patterns and by a more accurate schematization of sediment characteristics.
\end{abstract}

Keywords: Sand Groyne, Delfland Coast, sand nourishment, sediment transport, Delft3D

\section{INTRODUCTION}

\section{Objective}

The main objective of this paper is to asses an innovative sand nourishment method to maintain a sandy coastline, by constructing small sandy headlands in the upper shoreface called Sand Groynes (see Figure 1). Sand Groynes contain $100.000-200.000 \mathrm{~m}^{3}$ of sand and are expected to redistribute in the alongshore due to the impact of waves and currents, in this way creating a sediment buffer in the upper shoreface.

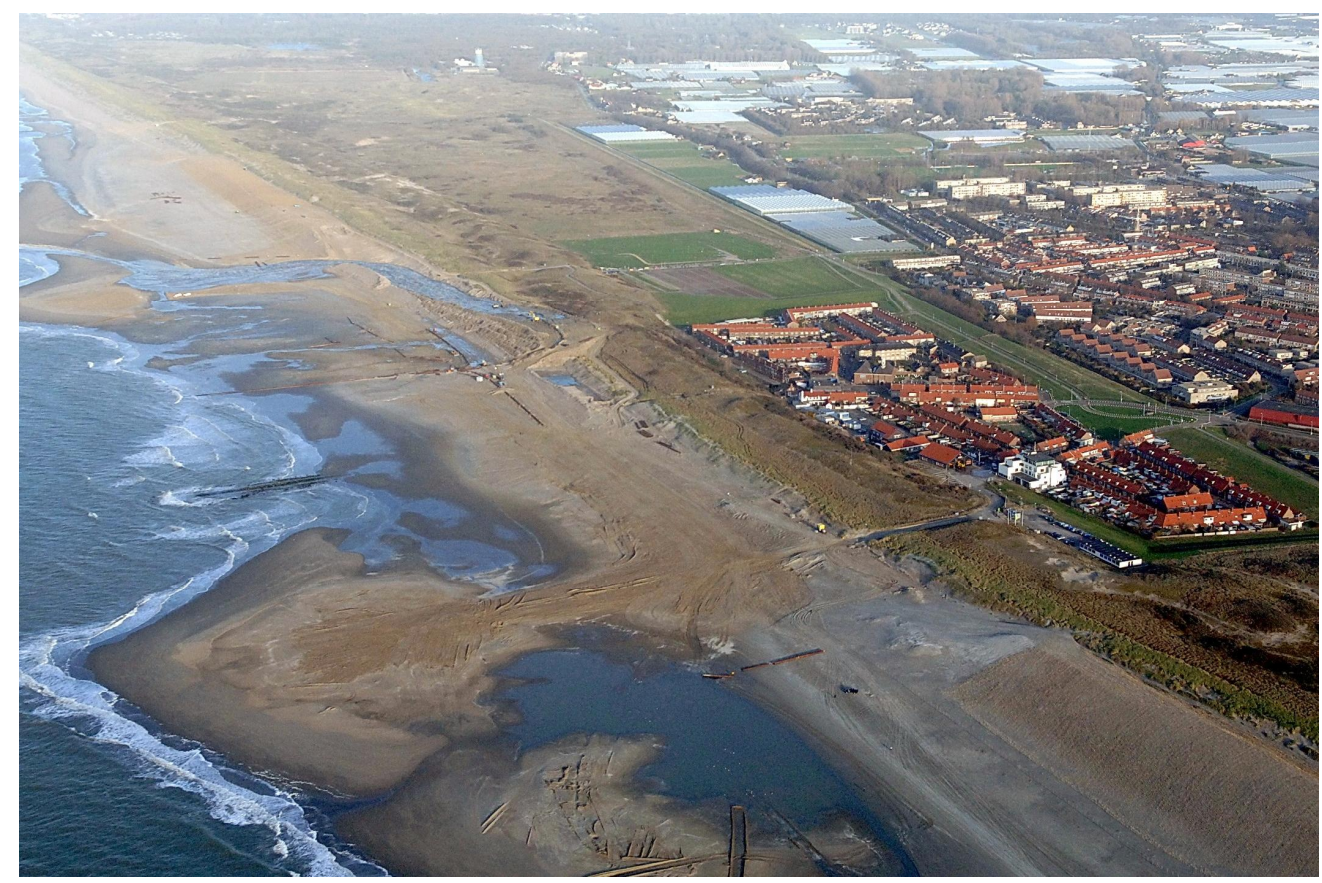

Figure 1. Aerial photo of a Sand Groyne at the Ter Heijde Coast, taken on 10 November 2010 (property: Van Oord Nederland).

\footnotetext{
${ }_{1}^{1}$ Deltares, Hydraulic Engineering, PO Box 177, 2600 MH, Delft, The Netherlands. roderik.hoekstra@deltares.nl ${ }^{2}$ Delft University of Technology, Faculty of Civil engineering and Geosciences, Section Hydraulic Engineering, PO Box 5048, 2600 GA, Delft, The Netherlands
} 
As a part of the Delfland Coast Restoration Program (project: Zwakke Schakel Delflandse Kust), three Sand Groynes have been constructed along about $2.5 \mathrm{~km}$ of coast near Ter Heijde village (see Figure 2, bottom panel), in October and November 2009. The Delfland Coast Restoration Program started in November 2008, aiming at restoring the sediment buffer along the Delfland Coast, which is the $15 \mathrm{~km}$ long stretching coast between the villages of Hoek van Holland and Scheveningen (see Figure 2, top panel). The project scope involves the restoration of the coastal profile from the dunes to the $-5 \mathrm{~m}$ NAP depth contour by supplying $15 \mathrm{Mm}^{3}$ of sand, by approximation equally divided over the dunes, the beach and the upper shoreface.

The construction of the Sand Groynes has been a pilot project to a subsequent pilot project at the same stretch of coast and following a similar nourishment philosophy: the construction of the Sand Engine (in Dutch: 'Zandmotor') (Mulder et al., 2012). The Sand Engine comprises a so-called meganourishment, originally containing an amount of $20 \mathrm{Mm}^{3}$ of sand, supplied in a hook-shape at the Delfland Coast in 2011. Similar to the evolution of a Sand Groyne, it is anticipated that this nourishment will redistribute in the alongshore due to the impact of the wind, waves and current, however with an expected lifetime of about 20 years.
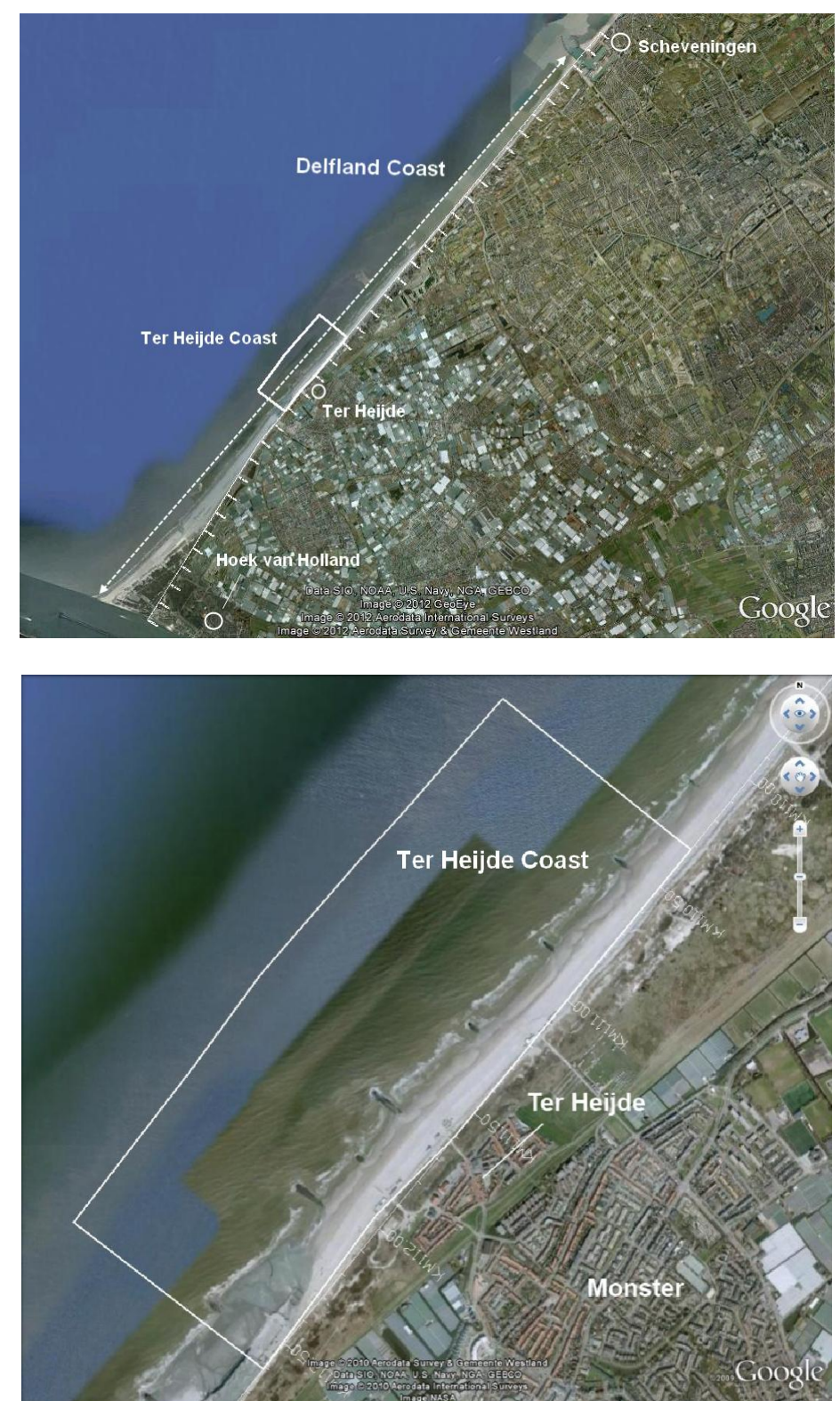

Figure 2. Planform view of the Delfand Coast (top panel), and the Ter Heijde coast (bottom panel) (source: Google Earth). 
New insights in sea level rise and the effects of climate change on the coastal evolution led to an inventory of coastal stretches along the Dutch coast, recognized as being not sustainable against the impact of the sea in the coming 50 years and in urgent need of restoration (Delta Committee, 2008). These stretches of coast, including the Delfland Coast, are further referred to as Zwakke Schakels (in English: 'Weak Links').

In the context of sea level rise and the effects of climate change on the coastal evolution, it is anticipated that the yearly required volumes of sand to maintain the Dutch coastline will increase significantly in the future. This prospect creates a need to seek for innovate nourishment methods that can efficiently supply these yearly required volumes. The method of constructing Sand Groynes to maintain the coastline reflects the Building with Nature philosophy. According to this philosophy, large amounts of sand are supplied in a relatively small area, while using the dynamics of the coastal system to redistribute the sand in the alongshore, creating the sediment buffer over a large stretch of coast and minimizing the frequency of disturbing the ecosystem.

Application of Sand Groynes to maintain a sandy coastline has a potential to satisfy the prospective amounts of required sand while improving the efficiency of dredging procedures, by supplying the sand concentrated. In this study the following objectives are addresses to contribute to the assessment of the Sand Groynes as a commonly applied nourishment method to maintain a sandy coastline:

1. Analyze the morphological evolution of the Sand Groynes

2. Set-up and validate a numerical model to simulate the morphological evolution of Sand Groynes Related to the proposed objectives, the following research questions will be answered:

1. What is the amount of Sand Groyne sand lost in offshore direction?

2. How far has the Sand Groyne sand been redistributed in the alongshore?

3. How does a Delft3D numerical model perform on hindcasting the morphological evolution of Sand Groynes?

\section{Approach}

In October and November 2009, three Sand Groynes have been constructed sequentially along the Delfland Coast, within a stretch of about $2.5 \mathrm{~km}$. The construction and subsequently the redistribution has been monitored (Hoekstra, 2010), by implementing different survey platforms measuring the bathymetry and elevation of the beach and the dunes. The monitoring campaign has resulted in a dataset that is used to analyze the morphological evolution of the Sand Groynes. Furthermore, hydrodynamic and meteorological data was collected which is used to force and validate a Delft3D numerical model.

The bathymetry datasets have been analyzed to trace the redistribution of Sand Groyne sediment to estimate the spatial scale of alongshore redistribution of the sediment. A Delft3D numerical model has been set-up to verify whether it can reproduce the morphological evolution of the Sand Groynes and to estimate the offshore losses. A properly validated numerical model would be very useful for the assessment of alternative nourishments and forcing scenarios. Since the considered period was relatively short, direct morphodynamic hindcast simulations were performed in which the observed hydrodynamics were directly imposed on the model. The model is calibrated and validated for hydrodynamics, consequently applied for reproducing the Sand Groyne morphodynamics.

\section{PROJECT: ZWAKKE SCHAKEL DELFLAND COAST}

\section{Pilot project: Sand Groynes}

The construction of the Sand Groynes has been executed as a pilot project within the scope of the Delfland Coast restoration project (Project: Zwakke Schakel Delfland Coast). Table 1 presents some characteristics of the overall project, the relevant project phase and the pilot project Sand Groynes.

\begin{tabular}{|c|c|c|}
\hline $\begin{array}{ll}\text { 1. } & \text { Project: } \\
& \text { Zwakke Schakel Delfland Coast }\end{array}$ & $\begin{array}{ll}\text { 2. } & \text { Project phase: } \\
& \text { Ter Heijde nourishment campaign }\end{array}$ & $\begin{array}{ll}\text { 3. } & \text { Pilot project: } \\
& \text { Sand Groynes }\end{array}$ \\
\hline $\begin{array}{l}\text { November } 2008-\text { April } 2011 \\
\text { Delfland Coast }(16.5 \mathrm{~km}) \\
15 \mathrm{Mm}^{3}\left(\sim 0.9 \mathrm{Mm}^{3} / \mathrm{m}\right)\end{array}$ & $\begin{array}{l}\text { September } 2009 \text { - January } 2010 \\
\text { Ter Heijde Coast }(2.5 \mathrm{~km}) \\
2.35 \mathrm{Mm}^{3}\left(\sim 0.95 \mathrm{Mm}^{3} / \mathrm{m}\right)\end{array}$ & $\begin{array}{l}\text { October } 2009 \text { - November } 2009 \\
\text { Ter Heijde Coast }(2.5 \mathrm{~km}) \\
0.55 \mathrm{Mm}^{3}\left(\sim 0.22 \mathrm{Mm}^{3} / \mathrm{m}\right)\end{array}$ \\
\hline
\end{tabular}


The Delfland Coast restoration project started at the coast of Hoek van Holland in November 2008, working upward north to Scheveningen to finish in April 2011 (see also Figure 2). In September 2009, the project arrived at the coast of Ter Heijde village (halfway between Hoek van Holland and Scheveningen, see Figure 2). The coast of Ter Heijde (see Figure 2) stretches about $2.5 \mathrm{~km}$ and was planned to be nourished with $2.35 \mathrm{Mm}^{3}$ of sand on the dunes, the beach and the shoreface (until the $-5 \mathrm{~m}$ depth contour), according to cross-shore design profiles. The Sand Groyne pilot project started in October 2009 with the construction of the first Sand Groyne at the coast of Ter Heijde. In total three Sand Groynes were constructed at the Ter Heijde coast, anticipated to redistribute in the alongshore at the Ter Heijde coast (stretching $2.5 \mathrm{~km}$ ) by the impact of waves and currents and partly settling the required volume of sand in the shoreface. Cross-shore design profiles prescribe sand to be placed until the -5 mdepth contour, hence offshore losses of sand (beyond $-5 \mathrm{~m}$ depth contour) had to be minimized as much as possible. Depending on the weather conditions and the available dredging capacity to nourish the sand, Sand Groynes were constructed within a time frame of 2-5 days. Table 2 presents the characteristics of the Sand Groynes constructed at the coast of Ter Heijde in October and November 2009.

\begin{tabular}{|l|l|l|l|}
\hline Table 2. Overview of Sand Groynes characteristics at the Ter Heijde coast. \\
\hline & Sand Groyne 1 & Sand Groyne 2 & Sand Groyne 3 \\
\hline Amount of sand $\left(\mathrm{m}^{3}\right)$ & 137.000 & 194.000 & 201.000 \\
Construction period & 15 Oct -20 Oct 2009 & 31 Oct -6 Nov 2009 & 7 Nov - 9 Nov 2009 \\
Net duration of construction (days) & 4 & 5.5 & 2 \\
$\begin{array}{l}\text { Location along RSP reference line } \\
(\mathrm{km})\end{array}$ & KM 110.700 & KM 110.100 & KM 111.900 \\
\hline
\end{tabular}

The last row of Table 2 indicates the position of each Sand Groyne along the Rijksstrandpalenlijn (RSP). RSP is an alongshore oriented measure line, essentially used as a reference to settle cross-shore profiles for the yearly organized JarKus coastal monitoring campaign.

\section{Sand Groyne monitoring campaign}

The design, construction and redistribution of the Sand Groynes areintensively monitored, by conducting regular bathymetry and beach surveys, taking sand samples, collecting dredging progress $\operatorname{logs}$ and making on-site photos. The monitoring campaign took place from September 2009, just before the construction of the Sand Groynes, until January 2010, when the Sand Groynes were almost completely absorbed into the coast.

Within this time frame, seven combined bathymetry and beach surveys are available on an averaged time interval of about two weeks. For each survey campaign carried out, multiple survey platforms have been implemented simultaneously to measure the bathymetry in the shortest amount of time, aiming for 'snapshot' recordings of the bathymetry. The following monitoring platforms have been used:

- Survey car equipped with RTK (Real Time Kinematic) and a single beam echo sounder to measure the beach.

- Jetski equipped with RTK and a single beam echo sounder, to measure the shallow part of the shoreface (until a depth of about -3m NAP).

- Survey vessel equipped with a multi beam echo sounder, to measure the deep part of the shoreface (from -3m NAP to further offshore).

Figure 3 gives an impression of the coverage of the survey campaign carried out at 15 and 16 December 2009. 


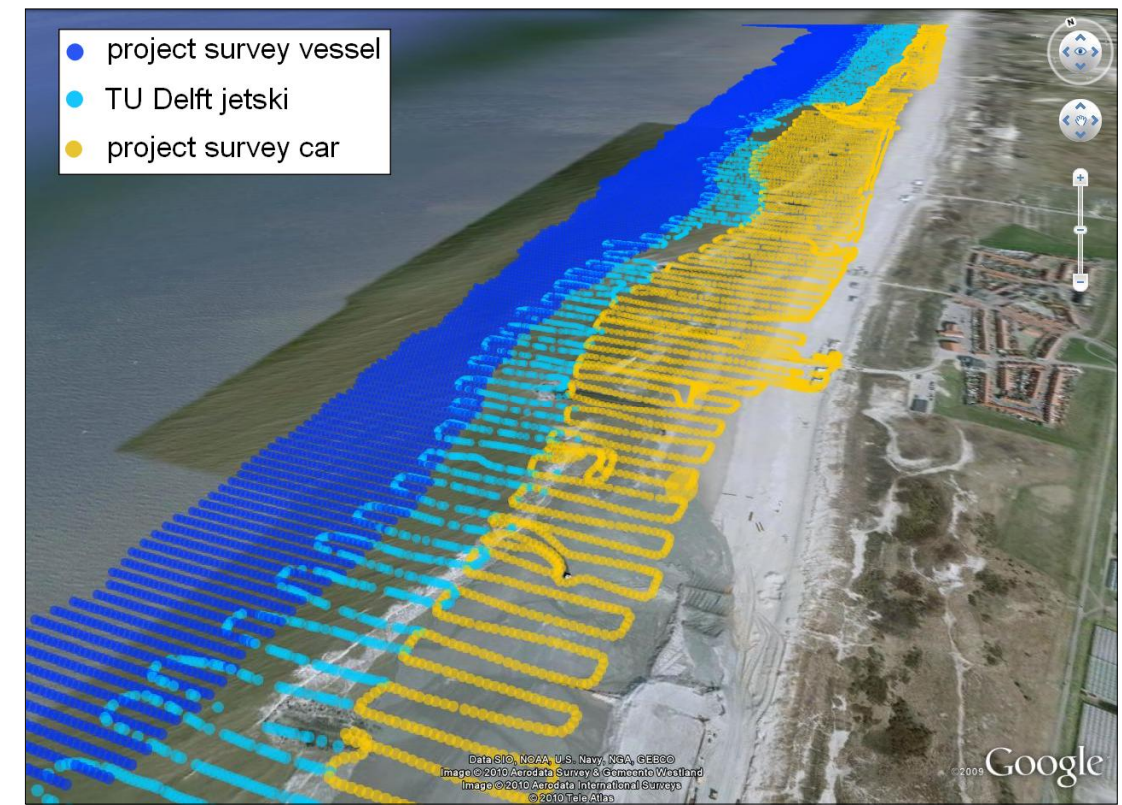

Figure 3. Birds-eye view of bathymetry field data coverage, obtained with different survey platforms (source: Google Earth)

\section{DATA ANALYSIS}

\section{Hydrodynamic conditions along the Delfland Coast in October - December 2009}

In the period October 2009 - December 2009, the Delfland coast was exposed to a moderate to severe, dominant south-westerly wave climate. Figure 4 presents wave roses, indicating the wave climate for the period between October and December 2009 (Figure 4a) and the averaged wave climate for this season (Figure 4b) based on wave data from the years 1979 - 2001, at several locations in the North Sea where waves are continuously measured by fixed monitoring stations.

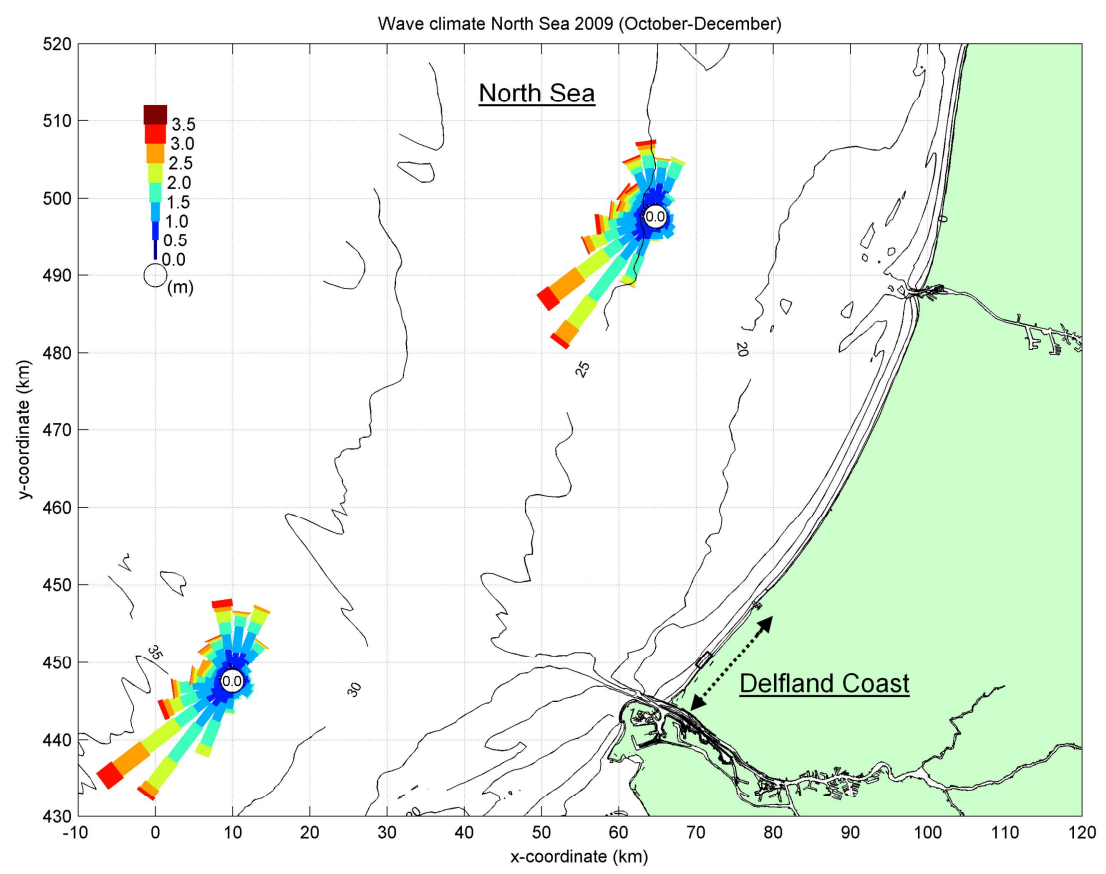

Figure 4a. Wave roses reflecting the wave climate in the North Sea for the period October - December 2009. 


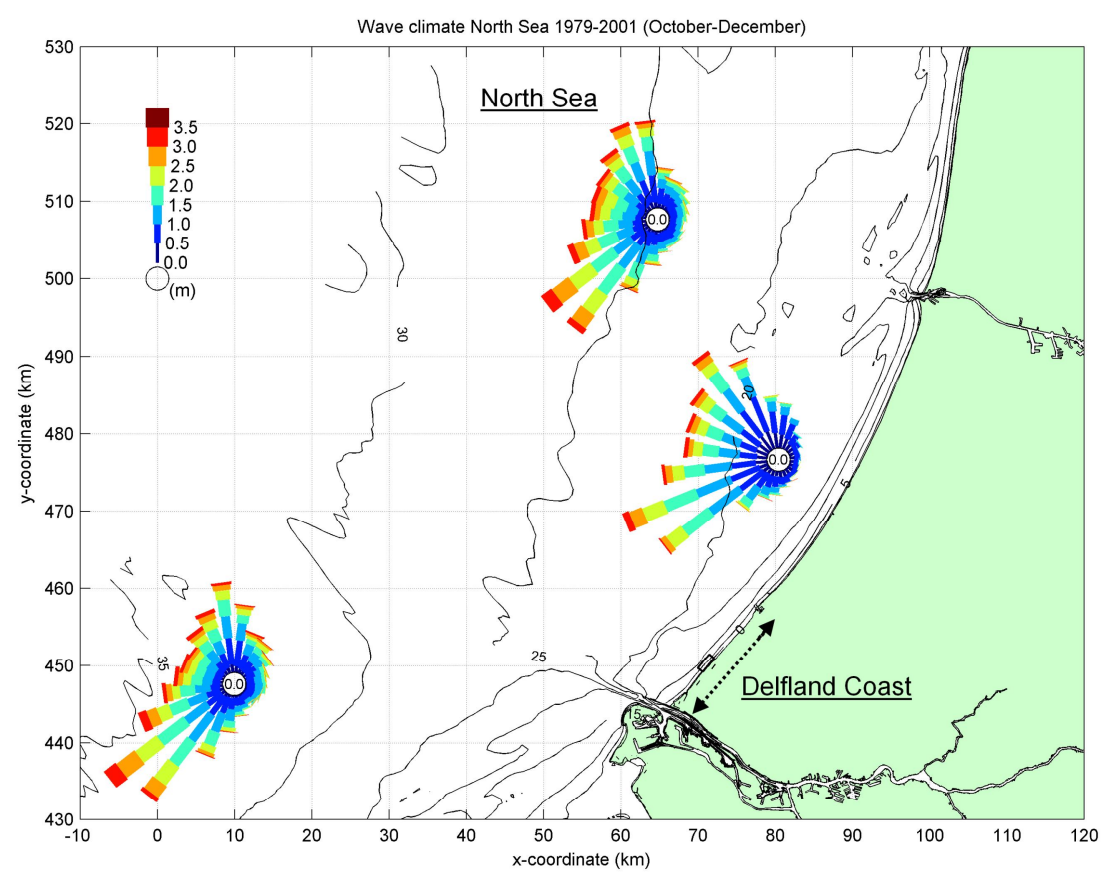

Figure $4 \mathrm{~b}$. Wave roses reflecting the averaged wave climate for the period October - December, based on wave data from the years $1979-2001$.

Figure $4 \mathrm{~b}$ indicates that the averaged wave climate for this period of the year is more evenly distributed over the western quadrant, although waves are still dominant south-west. For a more detailed analysis of the wave climate is referred to Hoekstra (2010).

\section{Morphological evolution of the Ter Heide Coast in September 2009 - December 2009}

The morphological evolution of the Ter Heijde coast is analyzed for the period of September 2009 - January 2010, based on two extensive datasets obtained prior and concluding to the Ter Heijde nourishment campaign. The datasets covers an area of about $8 \mathrm{~km}$ in the alongshore direction, facilitating an analysis of the morphological evolution of the Ter Heide nourishments on a relatively large spatial scale. Note that the Sand Groynes have been part of this nourishment campaign, accounting for about $20 \%$ of the volume required according to the design (see also Table 1).

Figure 5 present the cross-shore integrated development of sediment volumes, over the entire coastal profile from the dunes (+10m NAP) to the lower boundary of the upper shoreface (-5m NAP) in the top panel and for distinct parts of the coastal profile (dunes, beach, intertidal zone and upper shoreface respectively) in the bottom panel. Obviously, the figure indicates a net positive change of sand volume due to the Ter Heijde nourishments. The dashed, black vertical lines at KM 110.3 and KM 112.6 indicate the Ter Heijde nourishment site; accordingly the centerlines of the original locations of the three Sand Groynes constructed in the Ter Heijde nourishment site are indicated at KM 110.7, KM 111.10 and KM 111.90 (see also Table 1). 

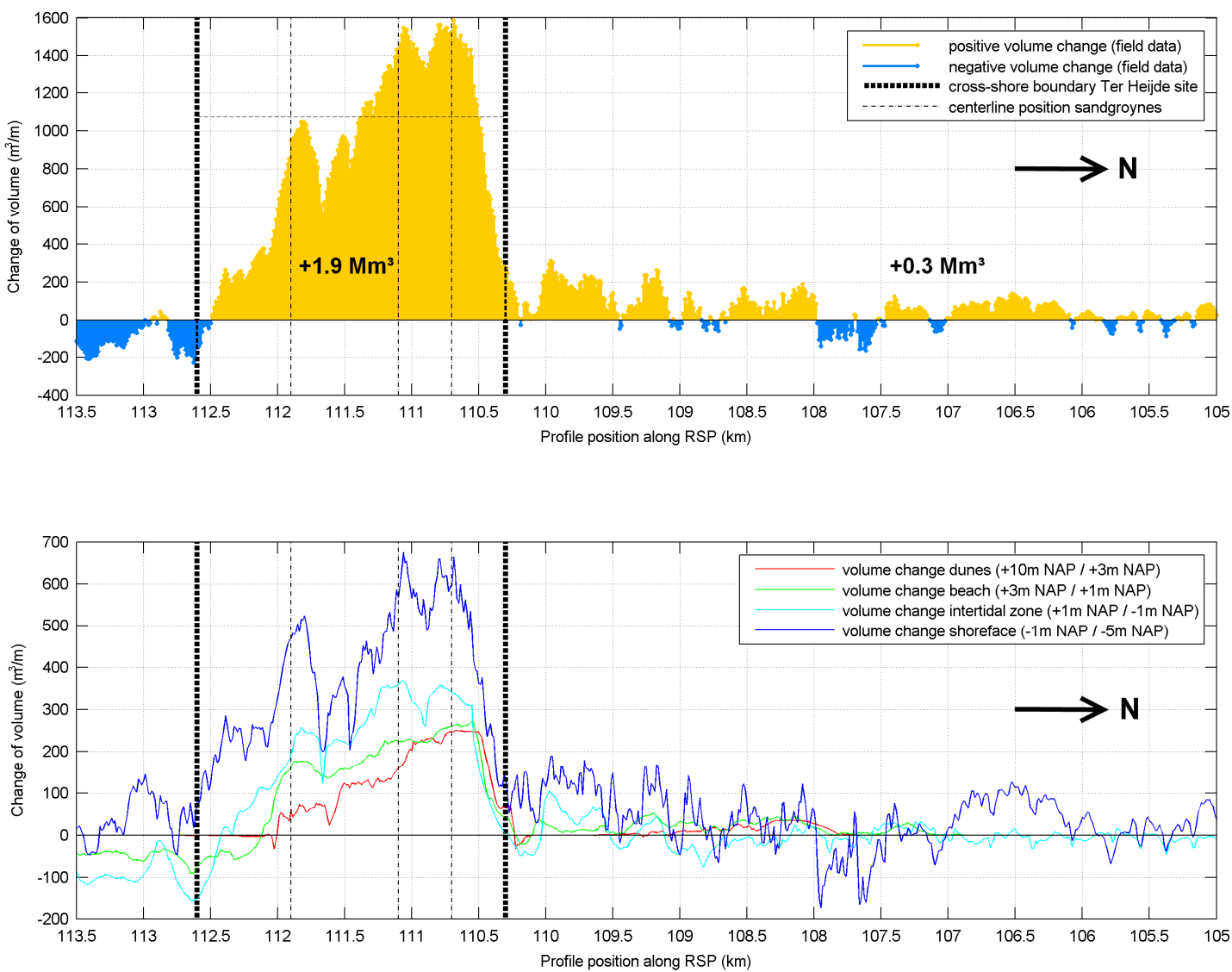

Figure 5. Cross-shore integrated development of sediment volume at the Ter Heijde and northern adjacent coast, over the entire coastal profile $(+10 \mathrm{~m}$ NAP / $-5 \mathrm{~m}$ NAP) in the top panel and for distinct parts of the coastal profile in the bottom panel.

In the period of September 2009 - January $2010,2.5 \mathrm{Mm}^{3}$ of sand has been nourished within the Ter Heijde nourishment site, based on progress figures delivered by the operating dredging vessels. This comes down to about $1000 \mathrm{~m}^{3} / \mathrm{m}$ when evenly distributed over the Ter Heijde nourishment site $(\sim 2.5 \mathrm{~km})$, which is indicated in the top panel of Figure 5 by the thin black, horizontal line. Based on the bathymetry surveys prior and concluding to the Ter Heijde nourishment campaign (of which the results are processed and presented in Figure 5), $1.9 \mathrm{Mm}^{3}$ of sand is traced on the Ter Heijde nourishment site; $0.3 \mathrm{Mm}^{3}$ is traced north of the Ter Heijde nourishment site. $0.3 \mathrm{Mm}^{3}$ is not traced with these surveys, possible accumulated outside the area covered by Figure 5. The net positive change of sand volume north of the Ter Heijde site can be explained by the dominant south-westerly wave conditions, generating a northward directed wave-induced alongshore current. The bottom panel of Figure 5 indicates that morphodynamic activity mainly only occurs in the upper shoreface, suggesting the wave-induced alongshore current to drive the morphodynamics.

Although the origin of the sand which has been transported northward can not be directly linked to the Sand Groynes, it is expected that the protruding shape of the Sand Groynes is sensitive for the alongshore current, with the capacity to transport significant amounts of the Sand Groyne sand. Figure 5 indicates that the nourishments executed in the Ter Heijde site have dispersed (KM 110.30 KM 112.60) in northward direction in the order of about $5 \mathrm{~km}$ (until KM 106.00), over a period of a few months time under moderate to severe, oblique incident waves. Further northward it seems that there is no net change of sand volume; in this region the local morphodynamics do not result in a net volume change. 
The bottom panel of Figure 5 presents the alongshore redistribution of sediment for distinct parts of the coastal profile: the dunes, the beach, the intertidal zone and the upper shoreface repsectively. Concerning the beach and the dunes, data is not available further northward of the KM 107.00 mark. Extrapolating the trend which is set southward of this mark, significant contributions of the dunes and the beach to a net change of volume are not expected. It is observed that the blue curve, representing the evolution in the upper shoreface, sets the signature for net volume changes both in the Ter Heijde site but also northward. Northward of the Ter Heijde site the net volume changes occur in the upper shoreface only; the intertidal zone, the beach and the dunes do not contribute.

\section{MODEL HINDCAST OF THE SAND GROYNE MORPHOLOGICAL EVOLUTION}

\section{Model set-up}

For the set-up of the Delft3D numerical model (Lesser et al., 2004, Van Rijn, 2003) reference is made to a cascade of models developed for a hindcast study on the Amelander Zeegat. This model instrument can facilitate a detailed hindcast study for a preferred location along the Dutch coast, based on meteorological and hydrodynamic data.

A cascade of Delft3D - FLOW model domains has been set up to simulate the impact of meteorological and astronomical forcing on the water level and current velocities. The model cascade consists of a range of coupled model domains, transferring boundary conditions from a large, relatively low resolution grid to the small, high resolution grid: the Continental Shelf Model (not presented), the Kuststrook model (covering the entire Dutch coast, red grid in Figure 6) and the Delfland model (blue grid in Figure 6), respectively.

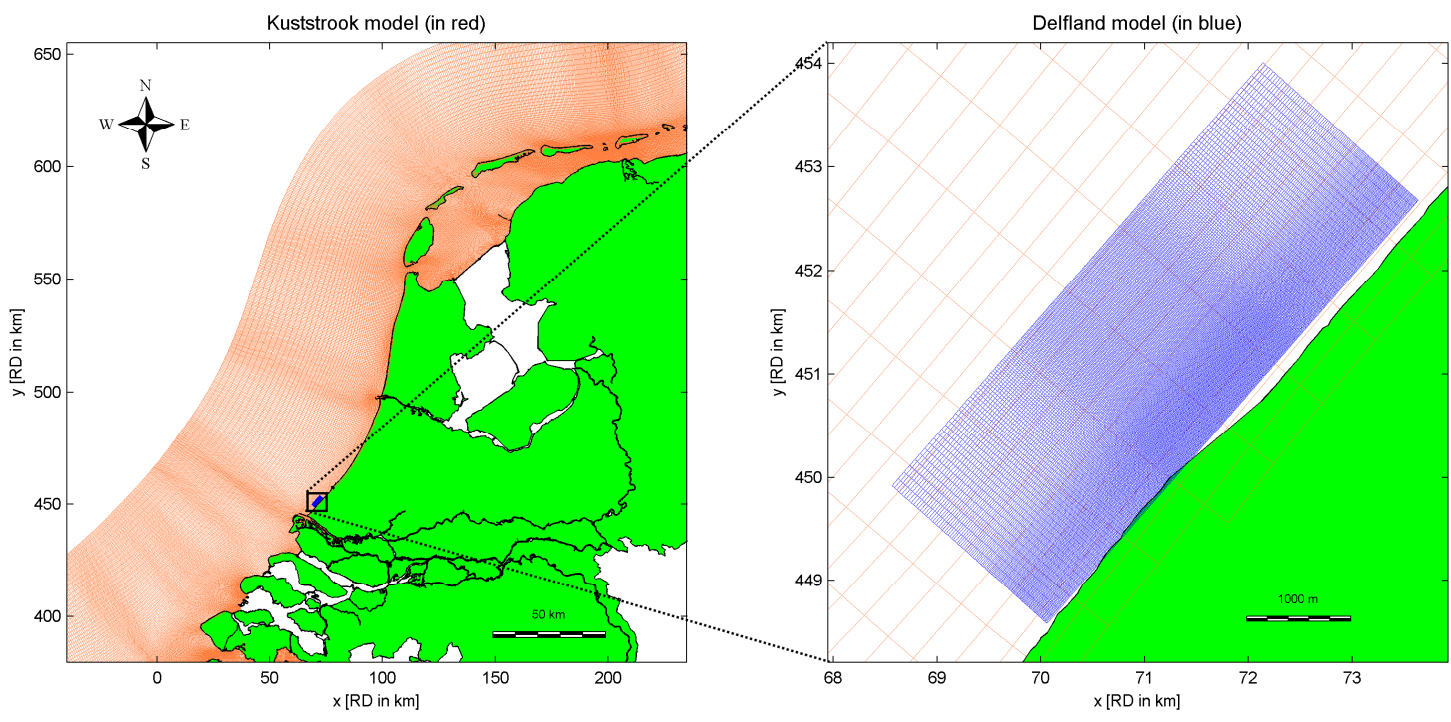

Figure 6. Planform view of Delft3D - FLOW model domains: Kustrook model (in red), Delfland model (in blue).

Delft3D - WAVE model simulations are separately performed on an alternative cascade of model domains (see Figure 7), transferring measured timeseries from the 'Europlatform' monitoring station in the North Sea, which is continuously measuring waves, to the nearshore. In the Delfland model domain, the effect of waves on current velocities, sediment transport and morphology (and vice versa) is accounted for by an online coupling of the WAVE module to the FLOW module.

The model has been successfully calibrated and validated for hydrodynamics (water levels, current velocities and waves) based on measurements of monitoring platforms located in the North Sea. For more information about the model set-up and the results of the validation is referred to Hoekstra (2010). 


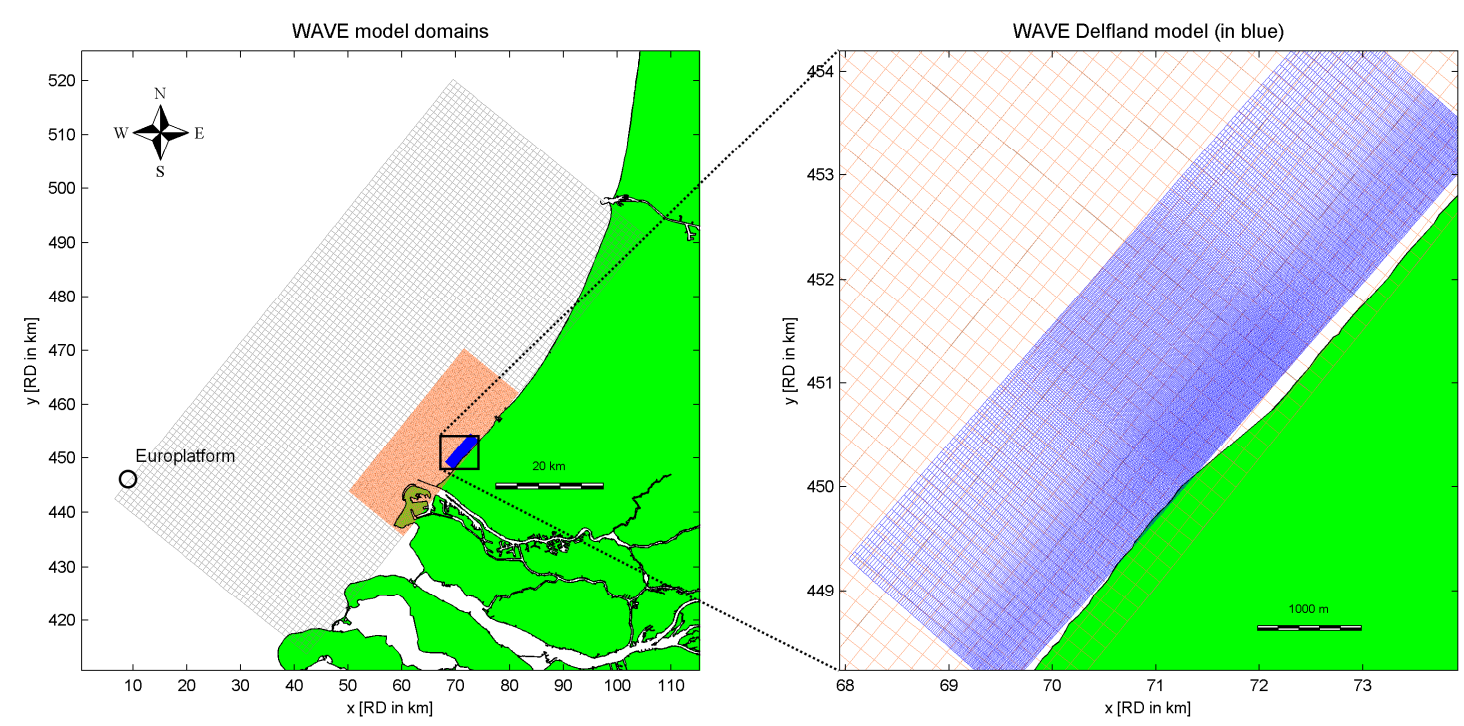

Figure 7. Planform view of Delft3D WAVE model domains, transferring offshore characteristics measured at the monitoring station 'Europlatform' to the nearshore.

\section{Model results}

Morphodynamic simulations have been performed for the period 16 November -2 December 2009. This period is preferred for a model hindcast because the dredging progress in terms of nourished sand has been very poor due to the bad weather conditions. Without significant dredging progress, bed changes are primarily induced by natural processes. This facilitates a comparison with model results, without interference of dredging operations.

The hydrodynamic conditions during this specific two-week period very much reflect the dominant conditions over the entire duration of the Ter Heijde nourishment campaign: moderate to severe, dominant south-westerly wave conditions (see also Figure 4a). Time series of measured wave characteristics (significant wave height and wave direction) at the Europlatform monitoring station are presented in Figure 8.
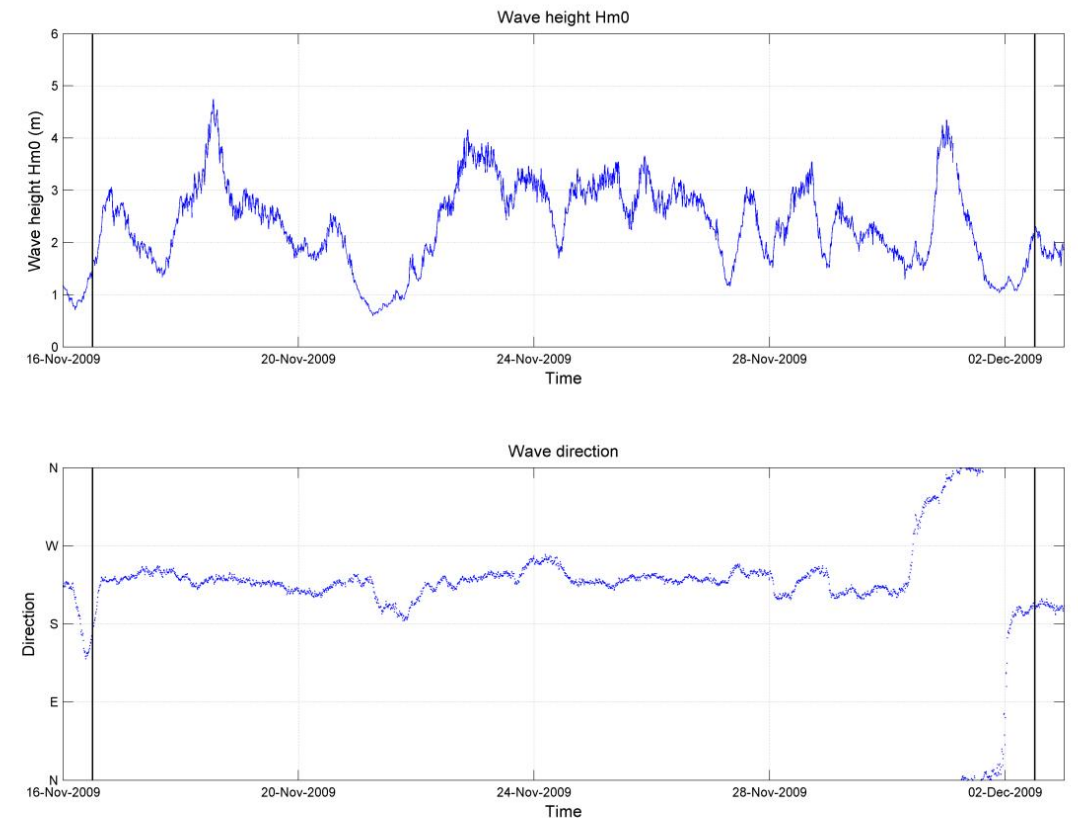

Figure 8. Timeseries of measured wave characteristics at the Europlatform monitoring station (16 Nov -2 Dec 2009): significant wave height ( $\mathrm{Hm0}$; top panel) and wave directon (nautical convention; bottom panel). 
Figure 8 indicates that the period 16 November - 2 December 2009 has been dominated by southwesterly waves, except for a short period at the end indicating a period of swell waves as the wave direction has turned north-west. Timeseries of wave characteristics presented in Figure 8 have been imposed on the wave model boundary of the largest wave model (see Figure 7).

Figure 9 presents the sedimentation - erosion patterns, based on field data (left panel) and model results (right panel), sedimentation in 'warm' colors and erosion in 'cold' colors. Grey lines indicate the contours of the initial bathymetry. Black lines with numbers indicate the original, alongshore position of the Sand Groynes (see Table 2 for an overview of the Sand Groyne characteristics).
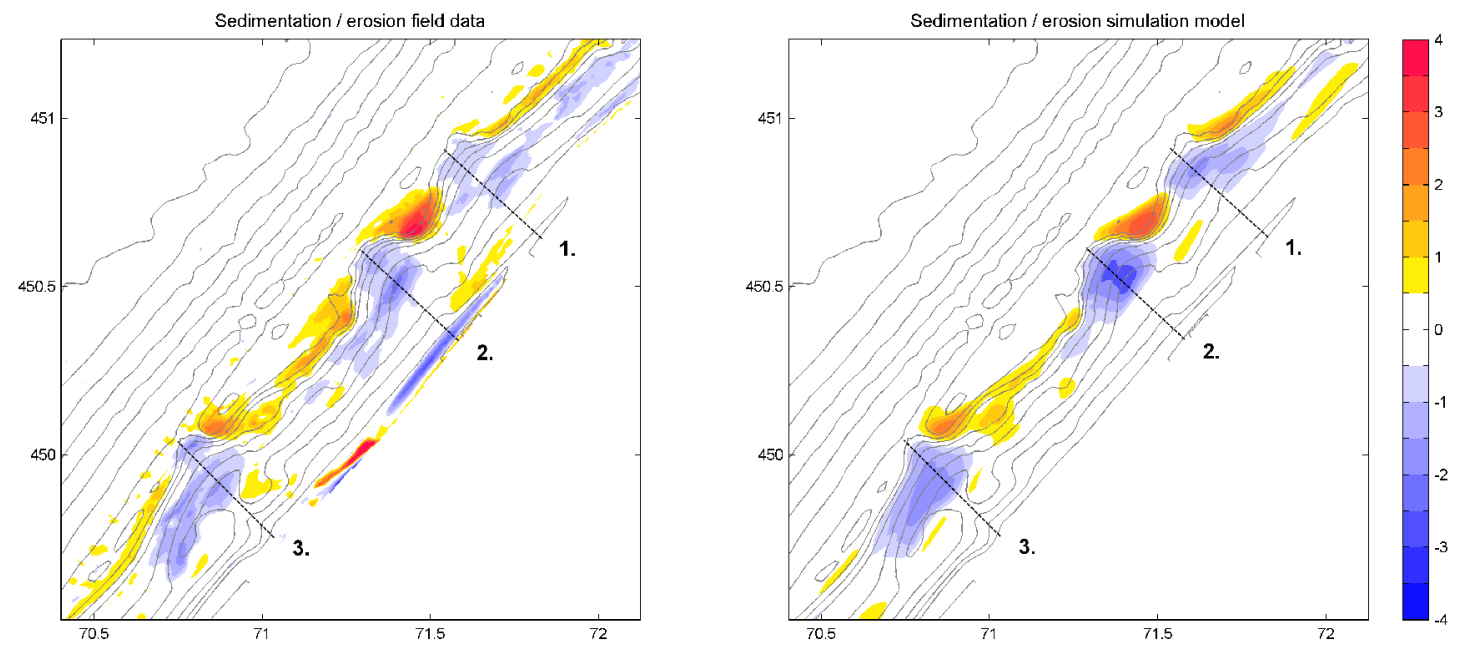

Figure 9. Sedimentation/erosion patterns between 16 November and 2 December 2009, based on field data (left panel) and model results (right panel). Sedimentation is indicated by 'warm' colors, erosion by 'cool' colors.

Overall, there is a good agreement between the field data and the model predictions. The Sand Groynes are dispersed, mainly in northward direction, indicated by the erosion patterns at the original locations of the Sand Groynes and the north adjacent sedimentation patterns. Both the model results and field data do not indicate significant offshore losses of sediment.

The sedimentation patterns just south of the $2^{\text {nd }}$ and $3^{\text {rd }}$ Sand Groyne tips are not reproduced by the model. At these locations, with shore normal parallel to incoming waves, it is expected that the sedimentation is induced by the return flow induced by breaking waves. A possible explanation is the poor representation of the vertical velocity profile in the breaker zone, due to the 2DH model set-up (depth-averaged mode) which ignores the 3D structure of the flow velocities across the water column.

Figure 10 presents the alongshore net change of sand volume over this 2-week period, cross-shore integrated from the transition between the dunes and the beach $(+3 \mathrm{~m}$ NAP) to the $-5 \mathrm{~m}$ NAP depth contour, based on the results presented in Figure 9. Stems represent net volume change based on field data; yellow indicates positive volume change and blue indicates negative volume change. The black curve indicates volume changes hindcasted by the model. The black arrow points towards the north. 


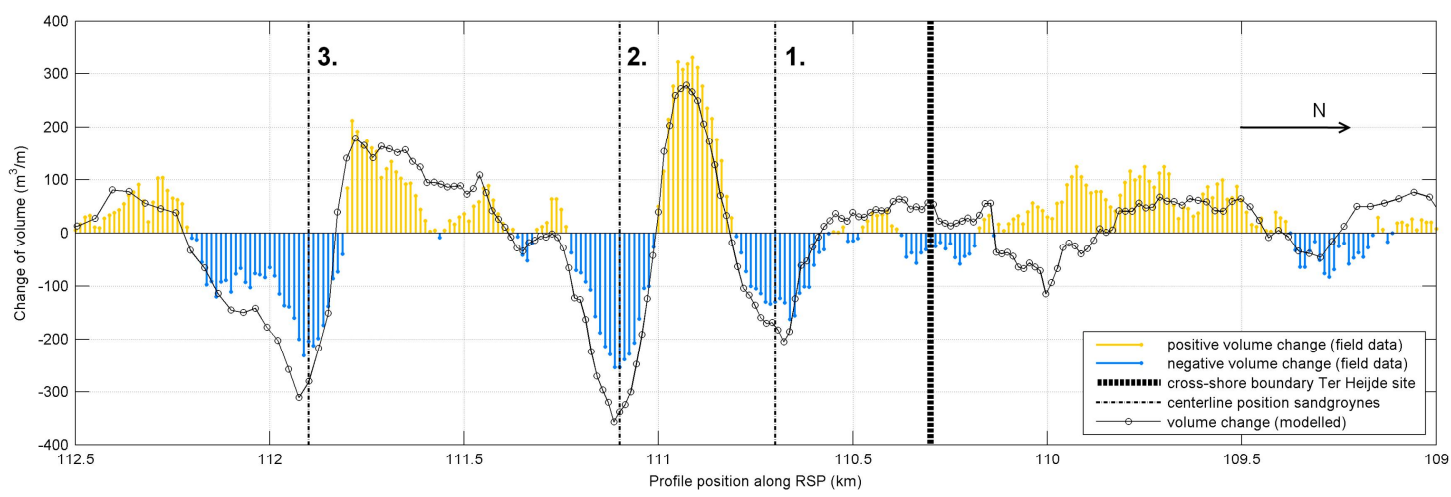

Figure 10. Cross-shore integrated change of sediment volume from $+3 m$ NAP down to $-5 m$ NAP, in the period 16 November -2 December 2009, comparing field data and model results.

Within the Ter Heijde site (KM 110.3 - 112.5), the trend of net volume changes based on field data are well reproduced by the model, confirming the sedimentation - erosion results presented in Figure 9. The negative change of volume at the original locations of the Sand Groynes, indicating redistribution of Sand Groyne sand, is still overestimated by the model. This could be explained by the poor model implementation of cross-shore directed transport, as discussed before. The lack of crossshore directed transport may result in a relatively large contribution of long shore transport on the redistribution of sand, transporting sand out of the cross-shore profile.

North of the Ter Heijde site (right side of Figure 10) a larger offset between field data and model results is observed. Although in small quantities, at the northern boundary of the Ter Heijde site (KM 110.30) the field data indicates sedimentation, whereas the model results indicate erosion. At KM 110.00 this is the other way around. This offset suggests that the alongshore redistribution of Sand Groyne 1 , in terms of spatial scale, is underestimated by the model. The model results indicate sedimentation within a range $0.5 \mathrm{~km}$ north of the Sand Groyne, whereas the field data shows sedimentation within a range of about $1 \mathrm{~km}$ north of the Sand Groyne. From KM 109.50 upward north the sedimentation - erosion trend based on field data is again picked up by the model. Further north of KM109.00, field data is not available for this period.

The results presented in Figure 10 suggest an interaction between the Sand Groynes. The down drift located Sand Groyne 1, relative to the dominant southwesterly wave conditions generating a northward directed current, seems to disperse over a larger spatial scale compared to Sand Groynes 2 and 3. This may be explained by the sediment trapping capacity of Sand Goynes. Sand Groynes 2 and 3 seem to redistribute over a smaller scale, where downdrift located Sand Groynes (Sand Groynes 1 and 2 repsectively) may act as a sediment trap. This possible interaction of Sand Groynes can be an interesting aspect for the design of coastal nourishment projects, providing the designer a measure to control the redistribution of sand.

\section{CONCLUSIONS}

\section{Conclusions}

In October and November 2009 the pilot project Sand Groynes has been executed at the Delfland Coast. Sand Groynes are small sandy headlands, nourished from the shoreline in seaward direction. The Sand Groynes contain $100.000-200.000 \mathrm{~m}^{3}$ of sand, anticipated to redistribute in the alongshore by the impact of waves and current to create the sediment buffer in the upper shoreface. This paper addresses the morphodynamics of the Sand Groynes using field data and a numerical model. The results should contribute to the assessment of the Sand Groynes as a commonly applied nourishment method to maintain a sandy coastline.

In the scope of the pilot project Sand Groynes at the Delfland Coast, three Sand Groynes have been constructed along a $2.5 \mathrm{~km}$ stretch of coast. Under moderate to severe, dominant southwesterly wave conditions the Sand Groynes have been redistributed mainly in northern alongshore direction. Offshore losses of sediment (beyond the -5m NAP) are not observed in the data analysis, neither in the 
model results. Field data indicates an alongshore redistribution of the Ter Heijde nourishments in the order of $5 \mathrm{~km}$, over a period of a few months time. Although the morphodynamic activity north of the Ter Heijde coast can not be directly linked to the Sand Groynes, it is demonstrated that the majority of the morphodynamic activity has occurred in the upper shoreface, where the Sand Groynes have been constructed.

A Delft3D numerical model has been set up to verify whether it can reproduce the morphological evolution of the Sand Groynes. A hindcast has been executed for the period 16 November - 2 December 2009. The modeled morphological evolution of the Sand Groynes indicates good agreement with the evolution observed in the field data. The overall trend of alongshore redistribution is well reproduced, especially given the fact the model set-up is in 2DH mode. Still the model performance could be further optimized by improving the implementation of some relevant processes and schematizations, such as a realistic implementation of flow velocities across the vertical and accurate representation of sediment characteristics.

Model results and field data analysis indicate a possible interaction between the Sand Groynes constructed at the Ter Heijde coast. The protruding shape of the Sand Groynes seems to have a capacity to trap sediment which is transported in the alongshore. This process is indicated by the first, most down-drift located Sand Groyne which is dispersed over a larger area than the two upstream located Sand Groynes. The suggested interaction of Sand Groynes can be an interesting aspect for the design of coastal nourishment projects, providing the designer a measure to control the redistribution of sand.

\section{ACKNOWLEDGEMENTS}

This research has been executed in the scope of a MSc-thesis, as partial fulfillment of the Hydraulic Engineering Master at Delft University of Technology (DUT), the Netherlands. Van Oord Nederland and Boskalis are acknowledged for hosting the pilot project, facilitating the monitoring campaign and providing bathymetry data, Deltares for facilitating the research and providing software tools. The MSc graduation committee, chaired by Prof. dr. ir. M.J.F. Stive (DUT) and delegated by S.G.A. Aarninkhof (Boskalis), G.J. de Boer (Deltares/DUT), A.L Luijendijk (Deltares/DUT), M. van Koningsveld (Van Oord/DUT), M.A. de Schipper (DUT), D.J.R. Walstra (Deltares/DUT) is acknowledged for their contribution to and supervision of this research

\section{REFERENCES}

Delta Committee, 2008. Samen werken met water, recommendations of the 2008 Delta Committee to the Dutch government.

Hoekstra, R., 2010. Pilot Sand Groynes Delfland Coast - Efficiency and practical feasibility of a pulse nourishment. MSc-thesis, Delft University of Technology (Netherlands).

Lesser, G.R., Roelvink, J.A., van Kester, J.A.T.M. and Stelling, G.S., 2004. Development and validation of a three-dimensional morphological model. Coastal Engineering 51 (8-9), 883-915.doi:10.1016/ j.coastaleng.2004.07.014.

Mulder, J., 2012. 'Sand Engine': first monitoring results of a mega-nourishment. Proceedings of the 33 rd International Conference of Coastal Engineering 2012. ASCE.

Van Rijn, L.C., 1993. Principles of Sediment Transport in Rivers, Estuaries and Coastal Seas. Aqua Publications, The Netherlands 